\title{
Major Leadership Features of the Peace Process in Colombia
}

\author{
Adriana Calderon
}

\begin{abstract}
This article examines the main leadership components of peace negotiations between the Colombian Government and the Revolutionary Armed Forces of Colombia (FARC) in Havana, Cuba. It identifies the leadership factors associated with the success of the four-year peace process that started in 2012, while comparing it to previous peace dialogues in Colombia to draw out the political learning process. The hypothesis is that three components, namely political learning in its complexity, the inclusion of women, and the inclusion of victims, have been crucial for the success of the peace process. Firstly, the concept of political learning is understood as materialising as a political leadership function. Second, in an idiosyncratic and to some extent patriarchal culture like Colombia's, it is essential to examine the role of women in the peace building process as engaging negotiators and mediators, rather than as only being passively exposed to politics. Third, the inclusion of victims in peace negotiations was an uncommon decision, and it appears to have eased the Accords. This article also contends that leadership as process, and in particular leadership styles, are fundamental to understanding the complexity that led to ending the world's longest-running civil war.
\end{abstract}

\section{Introduction}

On 26 August 2012 the Government of the Republic of Colombia and the Revolutionary Armed Forces of Colombia (FARC) came to an agreement to end Colombia's 52-year civil war. After six months of secret meetings in Havana de Cuba, from February September 2012 to, the President of Colombia, Juan Manuel Santos, and the negotiation leader of FARC, Ivan Marquez aka Timochenko, publicly announced that a negotiation process had been initiated. This made the world's headlines as it presented hope for what could end the longest civil war in the Americas. Almost four years later, on 23 June 2016, the end of the conflict was declared, with FARC agreeing to lay down their arms and Colombia's military to accept a consensual cease-fire. This is the third out of six accords, which was established and signed, covering the most controversial issues. This historic moment was broadcast live on big screens in the streets of Colombia. People were crying and hugging in celebration, and Colombians thought no one else could really appreciate their feeling about the importance of this act. 
On 24 August 2016, President Santos announced that the peace process had been successfully finalized when the Final Accords, a 297-page document, was released to the public. A plebiscite was planned for 2 October 2017 asking people to vote Yes or No to approve or disapprove the peace agreements. After thousands of deaths, millions of victims of torture and incarceration and a population living in constant fear for so many decades, the symbol of 'no more arms' meant the end of what had been a prolonged brutal conflict. After all, 8 million people suffered the consequences of this unjustified bloodshed, including the 6 million who were brutally displaced from their homes.

Nevertheless, a "No" vote won by less than $1 \%$, disapproving the peace accords. Groups that were against the accords, including the opposition, were invited to the Presidential Palace to work on amendments. After some amendments were made, President Santos decided to leave the decision of whether to approve or disapprove the Peace Treaty to Congress. In December 2017, the Agreement passed with a large majority in Congress. This paper, however, examines neither the plebiscite nor the reasons of the lost referendum. Its sole focus is on the Peace Process.

The origin of the war can be traced to the political situation during the 1940s, which was characterized by a bitter confrontation between liberals and ruling conservatives - a conflict that provoked unjustified bloodshed. Moreover, Colombia had been characterized by the power of the elites and the immense discrimination, influenced and fomented by actors against communism and leftist movements. Because of this, the strength the liberals were acquiring, and other politico-economic reasons, conservative governments wanted to take control of power and impede the comeback of liberals, who had been in office for fifteen years (1930-1945). Their political tool of choice was violence. A crusade of persecution against liberals started in 1945, in the middle of an agrarian reform that peasants and farmers demanded from the state, and which presented a big threat for conservatives' agrarian powerbase. ${ }^{1}$

After the liberal leader and candidate for presidency, Jorge Elieser Gaitán, was assassinated on 9 April 1948, from 1948 to 1958 a violent civil war, best known as La Violencia, dramatically impacted on all aspects of society. Guerrilla movements pushed liberal men, women and youth to take up arms following the anarchy and loss of identity as a result of their suffering. Like other insurgency groups, FARC became official in 1964, when two peasants and emerging leaders, Manuel Marulanda and Jacobo Arenas, led the FARC's first Conference in Marquetalia, Tolima. They claimed social justice to be their motive and violence to be their last resort with other political approaches blocked by the

\footnotetext{
${ }^{1}$ Historia: Instituciones de Colombia, Gobierno de Colombia (2002), p.4
} 
impregnable ruling elite. Ceasing power was considered the only way to defend their livelihood. Over time, and from both sides, however, a spirit of retaliation surged and took over the country and its people. Revenge for the evil they were exposed to became the incentive to act and the point of orientation for many. Still, since the 1980s, there have been more than 10 attempts to reach peace with FARC, but all except one failed.

An examination of leadership in this particular peace process is essential to better understand why it has been successful and what has worked and why, and what did not work and why. Furthermore, it will help to apply leadership theory in the context of Colombia's peace process, and to draw some lessons on how things could be done differently in future. Today, FARC acknowledges that engaging in politics is much better than engaging in violence for political power. To reach an agreement and end conflict took 52 years. This article addresses the major leadership factors in this peace process. What have been key leadership functions and what has been the role of these in the on-going negotiation between FARC and the Colombian government? It will be essential to understand whether these have played a key role in peace making.

\section{The Complexity of Leadership}

Leadership is a multifaceted concept that submits to competing definitions. There are many meanings and types of leadership known, but there are salient definitions in academia. This inquiry will touch on approaches to leadership as presented by scholars like Keith Grint and Peter Northouse, thus arguing that leadership is far more compound than most popular models imply and there is rarely a start or an end point to it. Grint discusses five approaches to leadership: person-based, position-based, process-based, results-based, and purpose-based. Person-based approach raises the question if it is who the person is that makes him/her a leader. Position-based approach refers to the where the person is that makes him/her a leader. Process-based leadership is the idea of leadership as an interactive process (often driven by a mutuality of people of similar motivations or in analogous circumstances). According to Northouse - who defines it as an influence process - it is when 'an individual influences a group of individuals to achieve a common goal'.2 Moreover, Grint asks whether it is how leaders get things done what makes them leaders? Leadership, Grint argues, is important to determine whether a peace process has worked or not. Leadership as results, according to Grint is asking if it is what leaders achieve that makes them leaders, which in the context of peace process one could argue that to achieve a peace accord is a big result. Lastly, leadership as a purpose as Grint's fifth and most

\footnotetext{
${ }^{2}$ Northouse, Peter (2014), Introduction to Leadership: Concepts and Practice (Michigan: SAGE Publications)
} 
recent approach entails if it is why leaders get things done that makes them leaders. ${ }^{3}$ Within Grint's framework, some approaches are considered to be especially relevant to the case of Colombia's Peace Process while others are not. Results are not yet palpable (hindering the measurement of effective leadership from results) and position is not considered a priority in this specific case. Although President Santos is often criticized, the whole governmental negotiating team is accountable for how things were done.

\section{Political Leadership and Learning}

Robert Tucker and Elock Howard explain political leadership and politics as leadership as one of the most complex and misunderstood phenomena. Furthermore, Elcock emphasizes the importance for leaders to exercise political learning as represented by various factors, such as drawing lessons learned and identifying an effective strategy. ${ }^{4}$ Tucker's relevant analysis allows leadership functions to take place in the political context and treats leadership as a process when engaging in politics. When power-holders use this to engage in politics and get things done, leadership happens. ${ }^{5}$ Applying Tucker's arguments in this context implies that the functions of leadership, and the conduct of leaders, have been essential to ending the 52-year long war in Colombia. The sole transition FARC has agreed to engage in is one from violence to politics, hoping that their leadership could better be applied in doing politics to get the social justice they claim they have been fighting for.

\section{Applying Leadership to a Peace Process}

Little research exists about the application of leadership theory to peace processes. Some scholars have studied types of leadership practiced in these contexts. Perhaps the most relevant is the case of Northern Ireland. An example is John Benington and Irwin Turbitt's application of Heifetz's Adaptive Leadership theory into practice in the Northern Ireland 2004 Peace Process context. Benington and Turbitt applied theory and practice, suggesting that applying adaptive leadership was necessary for a successful policing strategy in the Drumcree Sunday demonstrations. ${ }^{6}$ The application of leadership approaches mentioned in the previous section as well as political leadership through political learning and inclusion (particularly of women and victims) will

\footnotetext{
${ }^{3}$ Grint, Keith (2010), Leadership: A Very Short Introduction (Oxford: Oxford University Press), pp. 4-12

${ }^{4}$ Elcock, Howard (2001), Political Leadership (United States: The University of Michigan)

${ }^{5}$ Tucker C, Robert (1995), Politics as Leadership (United States: University of Missouri Press)

${ }^{6}$ Benington, John and Turbitt, Irwin (2007), Policing the Drumcree Demonstrations in Northern Ireland: Testing Leadership Theory In Practice (SAGE Publications: Los Angeles)
} 
be emphasised in this paper. As many scholars who argue that a leadership function is inclusiveness, collectiveness, and asking others to engage, examining inclusion in the Colombian context is, indeed, one of the priorities. Furthermore, the learning process from previous peace attempts, the transition and the adaptive learning, is a major component of leadership studied in this paper. It aims to apply functions as well as a combination of approaches to leadership.

\section{Contrasting Cases}

Two specific cases of peace processes with FARC will help understand the politics, civil society engagement, decision-making, what works and what does not work (within a leadership framework) and why. These are the 1998-2002 attempt under former President Andres Pastrana, and the current peace process, under President Santos, who assumed his first term in 2010 and got re-elected in 2014. The current peace process was chosen because clear leadership functions were identified, and thus a political learning process is possible. These two give a good representation of peace dialogues, but greatly differ in how they started, how they developed, the overall process, and their results. Finally, as there have been many guerrilla movements in Colombia, it would be easier to compare peace processes involving FARC than comparing two different guerrilla groups.

It is important to take into consideration the timeframe and the political situation, FARC's standing, and what the country was undergoing. Notwithstanding that previous peace processes and attempts in Colombia are equally important and fascinating, the one preceding the current peace process was chosen. There are clear distinctions and strong examples between the two cases, enabling a rich contrast and comparison. While Pastrana's Peace attempts now seem weak and were considered to be badly timed, Santos' supporters often say the team started at the right moment.

One of the main challenges faced in this study was that of maintaining objectivity at all times. Many of the available sources emanate from the military while others are based on testimonies from the FARC. In this case, it was a priority to find more neutral sources as well as reputable journalists or writers that shared both sides of the story to depict a balanced argument. Perhaps more central than secondary sources and theory, which are fundamental for this study, are those primary sources, interactions and interviews that enhance this research. Accessing these have been challenging due to the current polarized situation in the country. Given that the Colombian Peace Process is current, little information about this topic is found in academic literature. In addition, references to the leadership component and specific functions are rare. Some interviews were conducted by letter or telephone with those in Havana, Cuba. The sample includes those who were part of the 52-year long conflict, those who witnessed 
the terrible crimes committed, and those who today are experiencing peacemaking, often even the same people. Cross-sectional interviews were vital in order to avoid a biased perception becoming an obstacle, and allowing for surprises and varied information to be included. All Spanish documents, interviews, and texts have been translated by this author.

\section{The Colombian Context: History of Violence and Emergence of the Revolutionary Armed Forces of Colombia (FARC)}

Revolutionary movements in Colombia started as far back as the early 1800s, long before the emergence of FARC. Some historians attribute this to the formation of Colombia after colonization, understanding the violent encounter between the European colonizers and the indigenous people that greatly influenced the norms, rules and life style. ${ }^{7}$ Despite its relatively peaceful independence, Colombia experienced a civil war every 5-10 years from 1819, including the bloodiest la Guerra de los Mil Dias (Thousand Days War) from 1899-1902. The wars over power between federals (from 1848 known as liberals) and centralists (now known as conservatives), lasted until the 1886 instauration of the Conservative dominion for the next several decades. In the four decades that followed la Guerra de los Mil Días, the country's development flourished under a relatively peaceful and stable rule of law, with few exceptions. It was not until the mid-1940s that a period of violence that would last 52 years, began. ${ }^{8}$

As previously mentioned, one can see a legacy of war and the heritage of violence between the two main parties. A history of recurring violence and a spirit of revenge seemed to characterise Colombia's politics including a spirit of retaliation that led to a dehumanizing experience for many. With a violent contestation between the liberals and conservatives, each party was in office for a minimum of 15 years. In 1946, after the liberals had been in office from 19301945 , the new conservative government engaged in a crusade against liberals, to impede their return. ${ }^{9}$ In 1948, liberal presidential candidate Jorge Elieser Gaitán was assassinated before the elections, leading to a sustained period of bloodshed that lasted until 1958. The country embarked on a period where once again, the only response viable seemed to be violence.

These 10 years of civil war or La Violencia (1948-1958) was a period in which liberals took arms to defend themselves from the cruel attacks of the conservatives. ${ }^{10}$ Further, peasant families, who were not involved in politics, but

\footnotetext{
${ }^{7}$ Historia (2002), p.2

${ }^{8}$ Ibid, p.4

${ }^{9}$ Ibid

${ }^{10}$ Ibid, pp. 4-5
} 
were demanding land reforms, suffered because many children lost their parents through a policy of abductions and extra judicial killing. ${ }^{11}$ Those who had more liberal, or communist ideologies, or who claimed to speak up for the farmers, threatening the rich landowners, were targeted. They started movements that would eventually lead to guerrilla formations. Indeed, the understanding of past guerrilla movements and civil wars before and during the conservative hegemony (1886-1930) is crucial to comprehending the history and influence of armed insurgency. FARC was only one of the groups that emerged, hence to provide context, its origins will be emphasized in this history of violence.

Additionally, international revolutionary movements such as Fidel Castro's in Cuba and Argentinian Dr. Ernesto 'Che' Guevara (who supported the Cuban revolution and then sought to replicate it in the Congo and Bolivia) greatly inspired revolutionary movements in Colombia to grow and become official. Simultaneously, the CIA's and United States' government's overall obsession with stopping the domino effect (spread of communism in Latin America), while allying with the elites and conservatives, indirectly motivated these revolutionary movements. According to Marco Palacios, 'Colombia's sovereignty was limited by the elites pragmatic subordination to Washington's policies and paradigms, the Cold War, the war against drugs, and the war against terrorism and organized crime'.12 Of course, the liberals did not fall behind. Guzmán et al. suggest violence was a means through which to pursue rational goals, as each political party claimed their right to impose their ideals for a better Colombia. Yet, the ways physical coercion was exercised reached an extreme, 'losing the actions' initial philosophy and the conflict's ideology'.13

Perceptions, greatly influenced by the international situation at the time, favoured the conservatives more than the liberals. Taking advantage of the Cold War, and with the purpose of maintaining the hegemony, the conservatives were able to use the anti-communist language like 'revolution' as a negative, anarchic notion. ${ }^{14}$ Since these early communist movements in Colombia, there has been a tendency to support more conservative leaders in the political sphere and many rightists have dedicated efforts to deteriorate the reputation of the left, marginalizing it. ${ }^{15}$ It is important to clarify, however, that the rhetoric later used by the liberal party also included reference to armed liberals as bandits, and

\footnotetext{
${ }^{11}$ Arango, Carlos (1984), FARC (Bogotá: Ediciones Aurora)

12 Palacios, Marco (2012), Public Violence in Colombia, 1958-2010 (Bogotá: Fondo de Cultura Económica)

13 Guzmán, Fals, Umaña (1963), Violence in Colombia, p. 410

14 Grandin, G. and Joseph, G. M. (2010), A Century of Revolution: Insurgency and Counterinsurgency

Violence during Latin America's Long Cold War, p. 42

15 Palacios (2012), p. 31
} 
even among members of the same parties, significant divisions started to become more noticeable.

The approach of going around the country to support protests undertaken by the working class and farmers in the countryside, lasted many years while expecting results that were far from becoming real. Gaitan's assassination in 1948, followed by the conservative party's control over power, and the persecution that started with conservative President Ospina, kept feeding cycles of retaliation. Torres Restreo refers to this period as the one that 'constitutes for Colombia the most important socio-cultural change in the peasant areas since the Spanish conquest... a peasant class of revolutionary character'.16 To stop the 'terrorist violence of Ospina Pérez's government' (1946-1950) revolutionary movements got together in what they called the Revolutionary Conference. According to Arenas, this is when 'this fight started, a fight that hasn't ended and that we don't know when it will end'. ${ }^{17}$ It was not until 1964, however, that they officially declared themselves as a guerrilla group named FARC.

\section{FARC and Drugs: A love-hate relationship}

Many sources claim that external financial support clearly decreased in the early 90s (same period of a failed peace dialogue under Gaviria's presidency), and FARC needed a new income base especially to buy arms, because loss of support had dramatically affected them. Others argue that FARC had started in the drug business since the mid-1980s while some even claim they were already involved from the 1970s, when illicit trafficking became a major issue in Colombia. ${ }^{18}$ When interviewed by Semana in 1999, the biggest weekly magazine, Tirofijo, one of FARC's commanders, stated, 'oh, yeah! That's what they say we live off. The official policy even says that getting rid of cocaine will mean getting rid of us, as if coca was our revolutionary source...' arguing that the roots of the guerrilla movement was never cocaine, but the social injustices, and the economic and political problems of the country. ${ }^{19}$ Major Luis Alberto Pulido, in service in Colombia's Army when he wrote his book, shared official reports suggesting that FARC's strong involvement with cocaine and marihuana fields dates back to the 70s. What seems to be more consistent among sources is how FARC was involved in the drug business. Similar to other observers of the situation, Mayor Pulido argues that FARC's main roles included allowing drug-lords to plant cocaine in

\footnotetext{
16 Torres Restrepo, C. (1963), La violencia y los cambios socioculturales en los áreas rurales colombianas

17 Ibid. Arango"s interview to Manuel Marulanda continues several pages to question his life as FARC commander but also as a person and as Colombian.

18 Anonymous

${ }^{19}$ Semana (1999), Tirofijo se Destapa
} 
their territory of control, and the construction of airways in exchange for 'taxes.' Some of these taxes were paid to the peasants and countryside accomplices. ${ }^{20}$

As aggregated by Semana, the most important weekly magazine, ${ }^{21}$ during the conflict paramilitaries committed 8,902 targeted killings (highest of all groups), 1,166 massacres (7,160 deaths), 371 tortures, 1,000 recruited children, and 800,000 abandoned hectares (they account for kidnappings). Guerrillas had, 24,482 kidnappings, 3,900 targeted killings, 700 urban victims, 854 attacks, 77 terrorist attacks, 343 massacres, and 4,000 recruited children. The Armed Forces had 2,399 targeted murders, 158 massacres (870 deaths), 182 attacks, 71 urban killings, and undetermined number of tortures and forced disappearances. Victims include community leaders, human rights advocates, military personnel, and politicians. Simultaneously, a war between the state and the drug traffickers had started in April 1984 following one of the many assassinations by Pablo Escobar, of Rodrigo Lara Bonilla, Defence Minister at the time, and whose policies were very strict in the bid to end the drug cartels in the country.

The reorientation of the Colombian economic and pacification policies, then, created a phenomenon of guerrilla expansion. Official reports suggest that close to $60 \%$ of 'departments in Colombia experienced some kind of "guerrilla presence" in the mid-1990s.' 22 After 52 years and millions of victims, war with FARC appears to be coming to an end. Nevertheless, former president and leader of the opposition Alvaro Uribe, has campaigned against the Peace Accords.

\section{A Successful Peace Process: The Analysis of Leadership and Lessons Learned in four years negotiating the end of five decades of conflict}

In February 2012, secret conversations between the government and the FARC were being held in Havana, Cuba, to dialogue about the prospect of peace negotiations. President Santos invited FARC to negotiate so as to put an end to the conflict. They accepted. Howard Elcock's political leadership approach is of great relevance here, as he discusses the importance of recognizing leadership functions to help leaders effectively implement them and make quality decisions. ${ }^{23}$ Interviewees who participated in this research, such as Head of the Government's Delegation, Humberto de la Calle, suggested that Santos' good decision-making in beginning a process at the right time was essential for this process to get so far.

\footnotetext{
20 Pulido, Luis Alberto (1996), El Cartel de las FARC

${ }^{21}$ Semana, 2016, http://www.semana.com/especiales/escala-violencia-colombia/asesinatosselectivos.html

22 Echandía Castilla, Camilo \& Escobedo, Rodolfo (1994), Violencia y Desarrollo en el Municipio Colombiano (Bogotá: Presidencia de la República)

23 Elcock (2001)
} 
The negotiations demanded that nothing was agreed until everything was agreed. Creating the sub commission of gender and being an inclusive peace process were priorities. This time, both delegations had women as negotiators. However, the number of women participating in the negotiations was not representative. Both delegations comprised at least nine plenipotentiaries (the number of the delegates varied since the start in 2012), where at least three quarters were men. The Office of the High Commissioner for Peace, Sergio Jaramillo, presented seven official delegates of whom only one was a woman. Similarly, FARC had 40 members in Havana with only one woman present at the negotiating table at any time. News articles report that 20 out of the 40 support staff, however, were women; their tasks included writing and blogging. ${ }^{24}$ In addition, the substantive accord includes six components on 297 pages, with various elements each of which will be discussed selectively: the land and agricultural reform; and political participation. The latter was fraught with contentious points around power sharing in parliament in relation to the reserved seats.

However, as all agreed, the curules given to FARC'S political party were five in the Senate (out of 102) and five in the House of Representatives (out of 166). For the first few months, while laying down their arms, FARC would only have a voice in Congress, but no vote. The third accord was to mark the end of conflict, entailing the reinsertion to civil life; a process of giving all arms to the United Nations before demobilizing, which was agreed to take place in 22 concentration zones; and the ceasefire process. In these zones, however, only UN unarmed officials were to be present, and in the period of 90 days, after an interval of the failed referendum, all arms were finally laid down.

FARC sought guarantees of security given previous experiences. In 1990, months after a peace accord had been signed with M19, the second largest guerrilla group of that time, the extreme political right killed several M19 commanders. Carlos Pizarro, who was a presidential candidate at the time after M19 had gained political rights, according to one observer, 'was assassinated after M19 had demobilized. He was a man with ideals, who committed mistakes, but who I enjoyed talking to in my many visits to jail for interviews'. ${ }^{25}$ Gerardo Ardila, former Commander of M19 said he was surprised as they had 14 men total protecting them: 7 from the former M19 members and 7 from the government. Still, many of his compañeros had been killed. ${ }^{26}$

\footnotetext{
${ }^{24}$ Semana Magazine, Jairo Tarazona (2016), http://www.semana.com/nacion/articulo/dialogoslas-mujeres-de-las-farc-en-la-habana/464031

25 Interview with Monica Rodriguez, war journalist during the 70s, 80s, and 90s. She remains engaged in media, but retired from reporting. She and her family received regular threats.

${ }^{26}$ Interview with Gerardo Ardila, author, May 2016
} 
FARC, indeed, learning from these past experiences, wanted guarantees of security, worrying that the military, while officially protecting them, may make attempts against their lives. At the same time, the government worried that if armed former guerrillas were their only protection as security guards, society would feel threatened. For its importance, this point is discussed below.

The fourth accord, seeking solution to the problem of illicit drugs included essential components that could significantly reduce the country's drug production and trafficking. The fifth accord, which was at the centre of all negotiations, is treatment of and compensation for victims. ${ }^{27}$ The elements discussed and agreed in this accord include the judges for the Special Court for peace, and most important, the transitional justice framework including the victim's right to know the truth, those disappeared, and the measures for reconciliation, non-repetition, and the victims' integral reparation.

Under these, the government and FARC agreed that everyone (including military members in prison from the false-positive scandal mentioned below) would go under a transitional justice system. Guerrilla members, as long as they admit and recognize their crimes, would not undergo the regular jail sentence. Rather, they would have liberty restrictions, placed for example, on where they live (sleeping at a certain place and staying within a certain perimeter) or work (for instance, rebuilding schools they had burnt in the past). This would be studied and monitored on a case-by-case basis. If there were to be a case where a person does not admit their crimes, the consequences could be jail or prison term of up to 20 years. Efforts made by women's rights organizations, for example, are noteworthy. They lobbied and were able to include in the Accords that crimes such as sexual violence against women would not be amnestied. Both the government and FARC indicated commitment to contributing to truth-telling covering all years of conflict, including violations of human rights. Truth-telling is an incentive to be judged under the transitional justice framework. Some of the concerns expressed are that members might tell lies just to avoid the possibility of going to prison. ${ }^{28}$

This accord is given of special attention in this article, as the issue of victims is key concern at the centre of the Accords. Up until now, the exact number of militias is unknown, but within the framework, it has been clear that there will be lists with all members to apply for reinsertion as well as transitional justice (reports suggest there are 7.000 armed members of FARC, with unarmed, urban, being a similar number). When it comes to reparation, it is essential that the

\footnotetext{
27 The six accords have been extracted from the official document shared by the government and the following article: http://lasillavacia.com/historia/lo-que-esta-acordado-lo-que-esta-puntode-anunciarse-y-lo-que-falta-en-la-habana-56224 28 Ibid
} 
guerrillas ask for forgiveness. In 2016, FARC apologized to the victims in Bojayá, where they had attacked a church, killing more than 150 people and destroying a significant building for them. David Rieff noted, 'collective memory has led to war rather than peace and to the determination to exact revenge rather than commit to the hard work of forgiveness' ${ }^{29}$ In efforts to foment forgiveness, the psychosocial rehabilitation process will also be fundamental, as well as the accompaniment process to those displaced by conflict. The victims' Accords were not only based on assumptions, but they brought three large commissions of victims to the table in Havana to listen to their needs, concerns, and stories. What was extremely interesting to learn in one of the interviews conducted, was some of the victims' perceptions about the source of their pain.

Olga Amparo Sanchez, Director of La Casa de la Mujer, an NGO advocating for women's rights in Colombia, and who was invited to Havana several times as an advisor to the peace process, shared her insights. She said that the common attitude towards FARC, as assumed, was that they, as terrorists, were the only ones 'guilty' for the conflict. However, as some victims sat at the table, they asked FARC as well as the government to apologize. To them, although FARC had played the biggest role in conflict; the government had allowed this to happen because of the social injustice and inequalities the people faced. This was, Olga says, shocking for the government, as at first, the only 'ones who needed to apologize were FARC' ${ }^{30}$

The last accord is the phase of implementation, which included the plebiscite, international verification, and the overall budget to implement the Accords. For this last one, for example, the United States has offered USD450 million for post conflict activities. Yet, foreign aid often comes conditioned, so it will be in the hands of the government to ensure a fair agreement is made.

The exercise of leadership has been and will continue to be essential throughout the implementation process. In the following sections, it will be seen how from the beginning, many decisions made, though unpopular, were crucial to strengthen the peace process and avoid repeating mistakes from the past.

\section{A Piece of Leadership}

There were tensions and even exchange of fire in Colombia while the peace process was ongoing. Applying leadership in this scenario, Professor Keith Grint's views were extremely pertinent. He argues:

\footnotetext{
${ }^{29}$ Rieff, David (2016), In Praise of Forgetting: historical memory and its ironies (New Haven: Yale University Press)

${ }^{30}$ Interview with Olga Behar, May 2016
} 
'A peace process is much more complex than that. Therefore you have to engage not only in the leadership role, which I often define as the collaborative effort, so everyone has to be involved to some extent. But also to engage at some points, in the command issues, when things get really difficult [...] so you have to be able to be across various decision styles'. ${ }^{31}$

He notes that leadership is not linear, but often contradicting. In this opportunity, Santos, knowing that negotiations could end, gave the order of attack because he thought this would be the best decision. One could make a similar argument in regard to the shift Santos had between the previous government under Uribe's second term, where he served as Defence Minister (2006-2009), and when he became president in 2010. As Defence Minister under Uribe's presidency, Santos executed the tasks effectively, under a policy that entailed aggressively attacking the FARC to weaken them, but that implied a high peak during this war, with thousands of deaths, including many innocent people.

\section{Previous Attempts: Failed Starts and Political Learning}

By contrast, Uribe, whose father was killed by FARC, wanted to destroy it. Furthermore, as president, he was involved in various scandals like the 'falsepositive', where multiple media articles suggested he ordered a 'body count' tactic, regardless of who they were. According to these news stories, many peasant women and men demanded explanations for their lost children, and later, it would be known that many of these children had been accused of being guerrillas and killed by the military, in their efforts to present results and earn commissions. ${ }^{32}$ Additionally, as a landowner, and accused of being son of a drug trafficker in some testimonies, Uribe has been linked to the paramilitaries since his first term (2002-2006). ${ }^{33}$ Nevertheless, he was known for giving Santos the popularity to continue his legacy and follow his steps as elected president in 2010. At the same time, Uribe had invited FARC to start dialogues towards a peace accord, but it never happened.

Shortly after Santos assumed the presidency, rumours had started that he was initiating dialogues with FARC. By this time, Uribe's popularity remained high (not as high as his first term), and many people expected Santos to continue

\footnotetext{
31 Interview with Keith Grint, June 2016

32 Más de 4 mil casos de falsos positivos son investigados por la Fiscalía, El Espectador, 27 Sep 2014. Available at: http://www.elespectador.com/noticias/judicial/mas-de-4-mil-casos-defalsos-positivos-son-investigados-articulo-519238 (Accessed 7 September 2015); other news articles were consulted, as the false-positive scandal has been since 2008

33 Vieira, Constanza and Pineda, Chila (2016), Mujeres: Paz, y Política y Poder (Bogotá: Ediciones Aurora)
} 
FARC's extermination. The news surprised many Colombians who later started calling Santos a traitor and volatile. As leadership expert, however, Grint argues that sometimes, as a leader 'you have to be illogical to make sense of it... you have to be able to move from one to another', which implies taking decisions that are not necessarily popular such as starting a peace dialogue. ${ }^{34}$

As per Grint's statement, President Santos demonstrated leadership in his actions, even though elements of the public perceived them negatively. Nevertheless, the opposition has used its time well during the four years, ensuring that their followers, and if possible more people, joined their civil resistance and 'No' campaign. Leadership, as effective communication, had been, until June 2016, when the third accord (end of conflict) was signed, very weak from the government's side. ${ }^{35}$ This silence gave room to the opposition to spread their worries of the negotiations among society. However, neither Uribe, nor any representative from the opposition had been to Havana during the whole process. During Uribe's interview, later discussed, when I asked him about why he had rejected FARC Commander Timochenko's invitation to Havana, he said the opposition had been very clear from the beginning, about their discontent of having such a process. ${ }^{36} \mathrm{He}$ clearly appears to have no empathy for the enemy. This, as well as the possible reasons for this hermitic process or secretiveness will be touched upon in the following sections.

\section{Political Learning}

This section provides an analysis of the political learning process, and key leadership functions. Most sources consulted for this study agree that all past peace attempts with FARC only reached the phase of dialogues, never getting to the actual negotiation stage. Since 1980, close to ten attempts had been made to end conflict, specifically with FARC as the largest guerrillas. An important argument Eduardo Posada makes is the importance of both sides having the same understanding of 'integral peace' in the context of Colombia. ${ }^{37}$ Under this reasoning, former president Cesar Gaviria (1990-1994), seemed to have addressed this and given it the relevance it deserves. ${ }^{38}$ The 1991 dialogues, which started in Caracas, Venezuela, were moved to Taxcala, Mexico. Two incidents were determinant in the ending of the dialogues. Humberto De la Calle, current head for the government to the peace process, considered by many as a sensible, pragmatic, and ethical man, has had active roles in the previous dialogues, thus his perspective is quite insightful.

\footnotetext{
${ }^{34}$ Interview with Keith Grint, 2016

${ }^{35}$ Elcock (2001)

36 Interview with the Opposition leader, Senator and former president Alvaro Velez, 2016

${ }^{37}$ Posada, Eduardo (2002), La Paz y sus Principios (Colombia: Alfaomega Colombiana S.A)

38 Ibid
} 
In one interview De la Calle stated that in negotiations one can never guarantee everything will go as planned. This, he suggested, is because 'many times, conversations of this type end for external factors... in Caracas, 1991, the attempt to kill the Senate president, and then, in Taxcala, for the kidnapping' and death of former Minister Argelino Durán'. ${ }^{39}$ An anonymous source, who was close to the 1991 dialogues, argued that the death of Durán was caused by a heart attack, and the actual kidnappers were a small guerrilla movement also involved in the dialogue, but not FARC. A little persistence would have kept the dialogues moving. ${ }^{40}$ If Durán had suffered a natural death and FARC were showing real intentions to negotiate - in part because of the previously mentioned crisis in Cuba, Russia, and China, resulting in financial decadence for the guerrillas - were there enough reasons to end the dialogues? President Santos would have ended the peace process a long time ago. One should consider, however, that the priorities of the government at the time were the drug cartels that were hurting the country. Nevertheless, this priority may have caused an underestimation of FARC's eventual recovery, reinforcing its links with drug business, for financial stability.

Elcock, in recognizing leadership functions, suggests that political learning includes drawing on lessons learned, a right analysis of the situation at local, regional and international levels, anticipating moves, effective communication, and taking difficult unpopular decisions as well as sticking to them. ${ }^{41} \mathrm{His}$ arguments may help understand why President Santos and his delegation continued the negotiations despite the several attacks. When discussing the most recent peace dialogues, under Pastrana's presidency (1998-2002), which took place in Caguán, Colombia, several conclusions can be drawn. Olga Behar argues that Pastrana's process failed from the beginning. In an extensive interview, Behar, who defined the current process as 'the best possible, even if we wanted more...there are no perfect formulas,' suggests dialogues under Pastrana 'were born dead'.42 Confident, in May 2016 she said that the Final Accords under Santos' team were a matter of time. From the start, how Pastrana's process was designed, anticipated the failure for several reasons. The establishment of demilitarized zones while war continued, for instance, made the dialogues very hard to carry out. ${ }^{43}$

\footnotetext{
${ }^{39}$ El Tiempo, Ingreso de Farc en la política exigirá más a los partidos: De la Calle, 2016. Available at: http://www.eltiempo.com/politica/proceso-de-paz/entrevista-a-humberto-de-la calle/16680496 (Accessed 8 January 2017)

${ }^{40}$ Talk to an anonymous source, who participated in the 1991 Taxcala process

${ }^{41}$ Elcock (2001)

42 Interview with Olga Behar, May 2016

43 Palacios (2012), p. 158-159
} 
Moreover, an open agenda, with unclear purposes and objectives, or accords, caused clashes between government and FARC and various ruptures at the negotiation table, as both parts would pull their way. ${ }^{44}$ Contrary to Palacios, interviewees such as Behar suggest that Pastrana, by giving these demilitarized zones, was not dialoguing during war, and this accounted for the failure, as FARC gained strength. She states, 'Pastrana knew his prospect would not lead to demobilization, but repairing the victims was never in his mind,' and inclusion was poor. ${ }^{45}$ A historic picture released by the media in January 1999 shows la silla vacia (the empty seat), as Pastrana waits for FARC Commander, Marulanda who never showed up to the inaugural ceremony of the peace process, in fear that he would get killed. Behar concludes that there has been a clear political learning process, and it would be superficial to think that Pastrana's process ended because of FARC's provocations: 'in the previous process, they did not have any intentions in demobilizing, they were in a historic moment, stronger than ever, and Pastrana stimulated this power'. ${ }^{46}$ Robert Tucker argues that the:
'process of political leadership is activated, normally, when circumstances take on meaning for a political community or some important element of it, in such a way that the existence of a political problem or situation is recognized' ${ }^{47}$ In this process, 'leadership...is a task of diagnosing the situation authoritatively, devising a course of action designed to resolve or alleviate the problem, and mobilizing the political community's support for the leaders' definition of the situation and their prescribed policy response'. ${ }^{48}$

Both, Pastrana and Santos recognized the problem, but Santos' delegation was much more effective in designing to resolve or alleviate the problem of conflict. Additionally, the delegation took into consideration the lessons learned. Furthermore, Santos has been able to mobilize the necessary political support not to let the opposition have a majority in Congress. Besides the Senators (including Uribe) who were interviewed from El Centro Democratico, the opposition party, Senators across other parties different than Santos' were in favour of the peace process (according to hearings and interviews).

Finally, after many more negative than positive aspects in the balance, Pastrana's dialogues broke in June, 2002. FAC kidnappings had kept increasing throughout the period, as well as a historic strengthening of the military. But none of the parties were willing to advance. The threat by Mono Jojoy, former leader of

\footnotetext{
${ }^{44}$ Palacios (2012), p. 158-159

${ }^{45}$ Interview with Journalist Olga Behar, 2016

${ }^{46}$ Ibid

${ }^{47}$ Tucker C, Robert (1995), Politics as Leadership (United States: University of Missouri Press) 48 Ibid
} 
FARC, of taking over the capital Bogotá, seemed realistic. And as former Minister, Camilo González said, there was no clarity of how to move from dialogues to negotiating. ${ }^{49}$ Nevertheless, the last months of Pastrana's presidency, and the transition of power to Uribe, marked the weakest point of FARC. The Plan Colombia, financed by the United States, directing $80 \%$ of the budget to strengthen the military, declared one of the bloodiest wars with drug dealers and guerrillas during this long conflict.

As Humberto De la Calle expressed to this author in an interview, 'I have to highlight President Santos' audacity, as after all, he was the one who decided to start this and take these conversations over his shoulders...someone said continuing war would have been easier, it was inertia. To change things, implies leadership' ${ }^{50}$ Knowing Uribe's popularity, it is certain that continuing war would have been easier. He also highlighted Santos's persistence, referring to his service as a marine: 'in the ocean, the purpose is arriving at the shore, no matter the storms that may occur on our way'. ${ }^{51}$ But he also recognized the leadership from FARC, taking a decision that was extremely hard for them. This resonates with James Burns's theory on decision and change. He states 'as leaders they must avoid those pressures that would reduce their role to that of mere agent... they must avoid being drawn into and "morselized" by existing administrative arrangements, with their multifarious institutional demands'.52 'Our dialogues' according to Humberto De la Calle, 'have been constructive, honest, open...extremely different from the traditional pull and push, or the often I offer this to get this'. ${ }^{53}$

Going back to Elcock's leadership functions in political learning, drawing on lessons learned, and taking unpopular decisions, the connection to leadership is clear. De la Calle, when comparing the processes, touched on three substantial differences and lessons learned between the two, demonstrating the underpinning political learning. First, he said, avoiding at all costs, demilitarized zones. The delegation consciously took the precaution of not 'falling into this'. As he argued, this was catastrophic in the past, creating mobilization to demilitarized zones, generating huge controversies in Colombia, and serving as perverse incentive for FARC. Second (and mentioned later by many interviewees), and as a consequence of what was previously said, taking the process outside Colombia, in this case in Havana. And third, to have a clear agenda, which he underlined as being crucial while explaining that 'conceptually,

${ }^{49} \mathrm{El}$ Tiempo, El fracas de los dialogos de paz en el Caguán, 2010. Available at:

http://www.eltiempo.com/archivo/documento/CMS-8430440 (Accessed 8 January 2017)

${ }^{50}$ Interview with Humberto De la Calle, June 2016

51 Ibid

52 Burns, James (1978), Leadership (New York: Harper \& Row Publishers)

53 Interview with Humberto De la Calle, 2016 
one thing is to end conflict, and another one is to open the opportunities for peace.' To end conflict, an agenda of six accords was determined functional to ending a conflict. This way, he argued, they avoid, as much as possible, a past tendency to talk about perfection, and 'make the negotiation table a permanent forum, where everyone wants to go to, to express their hopes and frustrations.' This time, he said,, 'we have limited ourselves to keep the agenda and develop it to be able to end the conflict.'54 When asked during interview whether the Accords would be signed soon, he replied 'I hope so,' with a convinced tone, 'we are certainly working very hard for it to happen, and I can express the conviction from both sides that we want this to happen, and to happen soon.' Four days later, the Final Accords were released.

\section{Trust and Empathy: Two Significant Factors}

Trust and empathy are two essential factors that came up throughout this process. First, one has to consider the situation under which the peace process took place in order to understand why it was harder to build trust. One of the conditions set by the government, as a lesson learned, was to negotiate during conflict and not to assign demilitarized zones. De la Calle mentioned 'it's a hard job, but starting from the initial preventions, we were able to create an environment of transparency taking into consideration the antagonism that implies being in different conditions, different visions, but with the mutual motive of reaching accords. ${ }^{.55}$ To be able to move beyond the antagonism, trust and empathy from both sides were essential. Bernard Bass' Ability to Handle Conflict, suggests that 'effectiveness as a leader was associated with the ability to convert conflicts of interests into accommodations, conciliations, compromises, and better yet, conceptual agreements.'56 Both delegations were able to engage in this. Moreover, Walton argues, 'effective leaders did not run away from conflict'. ${ }^{57}$ Thus, language used by FARC in their blogs at the beginning reflected hostility in the table, but language changed as time passed, suggesting a build of trust and collaborative relationship.

\footnotetext{
54 Interview to Humberto De la Calle, 2016. He continues answering my questions in efforts to transmit a clear understanding of the implications of the process. Mentioning, for instance, efforts to prevent a repetition of what happened to commanders and members of the M19; and creating a robust system to protect the FARC members as well as Colombian communities. Also, tackling the bacrim problem (bandas criminals or criminal gangs, as well as paramilitaries) with specialized, new mechanisms.

55 Ibid

56 Bass, Bernard (1990), Handbook of leadership: Theory, Research and Managerial Applications (New York: The Free Press)

57 Walton, Richard E. (1972), Inter-organizational decision making and identity conflict (Chicago: Aldine)
} 
While Bass finds little connection between leadership and empathy, ${ }^{58}$ Grint argues that empathy, which facilitates the understanding of the other, 'is a prerequisite for addressing wicked problems' which according to him, is engaging in leadership. He notes, 'if you cannot understand how they see the problems, how can you mobilize them?' and thus, engage in collective efforts? ${ }^{79}$ Moreover, Northouse argues that a leader needs to have empathy for others, 'understanding the feeling of others as if those feelings were his or her own'.60 The argument presented in this context, then, is that both delegations lead and follow each other to reach a mutual agreement in a collective interaction.

During an interview with Piedad Córdoba, former senator for 20 years and human rights activist, she explained that generating trust was essential. Piedad has acted as mediator several times, traveling to Havana when needed, and confessed that although strong arguments still occurred, trust had evolved as FARC have demonstrated to commitment and work hard, reading the Accords every night. ${ }^{61}$ Northouse said, 'Special relationships are built on trust...are often initiated when a leader recognized group members who are willing to step out of scripted roles and take different responsibilities' ${ }^{62}$ In this context, most, with the exception of a few, many had to step out of their roles and become delegates representing their side. De la Calle stated, demonstrating the trust, that though FARC are very scared of the final steps of the process, 'I do believe they want this accord. They might have started probing the panorama, but today, they are honestly involved and committed to the decision of ending conflict'.63 This was confirmed by Timochenko's declaration in Havana as he said 'let's engage in peace together', and closed apologizing to all of those who suffered in this conflict. In the next section, this will be applied to the victims, as followers.

\section{Inclusion and Collective Engagement: What took so long?}

One of the most commonly identified lessons learned among interviewees was the creation of a clear agenda. Those in favour of signing this peace process expressed their admiration of the six accords despite the multiple fallacies. Moreover, the six accords encompass for many, essential components needed for solid, durable peace. Among those who identified and recognized leadership within the peace process, there seems to be consistency and synergy. Two main factors, arguing innovation and inclusion as leadership and political learning,

\footnotetext{
${ }^{58}$ Bass (1990), p. 118

${ }^{59}$ Grint, Keith (2010), Leadership: A very Short Introduction, (Oxford: Oxford University Press), p. 31

${ }^{60}$ Northouse (2014), p. 91

${ }^{61}$ Interview with Piedad Córdoba, 2016

${ }^{62}$ Northouse (2014), p. 91

63 El Tiempo, 2016
} 
that were the centre of this study and created constant, but also contradicting views, were the inclusion of victims and the inclusion of women as negotiators. Northouse's central approach to leadership is that of leadership as an influence process, 'whereby an individual influences a group of individuals toward a common goal... as an interactive event between leaders and followers, where influence is central... influencing individuals to achieve something together' ${ }^{64}$ In this case, five commissions of fifteen pre-selected victims each, mostly composed of women, were taken to Havana to talk to the delegations at the table. On the government's side, the delegation included the head of the negotiations, De la Calle; The High Commissioner of Peace, two Army Generals, and only one woman, María Paulina Riveros, who is a lawyer and human rights expert.

Similar to Northouse, Grint introduces a process-based leadership approach as a relational concept. He defines leadership as collective, inclusive and innovative, all of which suggest leadership was present in the Colombian Peace Accords. If we treat victims as followers, as according to sources, the majority want this peace process to happen, mutuality between the leaders and victims happens. Santos was not present in most of the negotiations so he needed to make sure the head and the whole delegation had empathy for the followers and was engaging. During our meeting, Keith Grint talked about the idea of people 'expecting you to be logical and linear'. Moreover, he argues and strongly believes that leadership is "this notion of giving the problems back to the people, but not only saying "this is your problem fix it," as I have to help you do this, but baring with you.' He argued that for wicked problems, in this case, including victims was absolutely right; 'in leadership, you have to innovate all the time. If it works keep going, keep doing it, if it doesn't, stop. Everything has to be reversible because you don't know if it will work.' He notes that engaging in a collaborative process is much harder. ${ }^{65}$ This is the first peace process in Colombia to make victims the centre and nucleus of the negotiations.

As per Grint's arguments, not bringing victims to Havana would have been much easier, as taking decisions and making assumptions for others, in this case 'those with the problems,' is often a path taken. Grint continued discussing the adaptive leadership method of cooking. He said, one has to cook problems, one has to make people responsible, engage them; 'they don't want to take responsibility, but you have to make them, make them so uncomfortable that they will do something, but if you make them too uncomfortable, they will just give up.' One of the biggest failures in political leadership, he notes, is wanting to be liked. The inclusion of the victims was extremely challenging, as they were asked what they wanted and how, reparation, healing, and forgiveness were perceived by them.

\footnotetext{
${ }^{64}$ Northouse (2014), P. 6

65 Interview with Keith Grint, 2016
} 
Surprising to many, however, some victims were very critical of the process, as well as engaged to find long-lasting solutions. This becomes even more inclusive as victims, while trying to create integral solutions, were not taken as a homogenous group, but as a very diverse group. Besides victims of FARC, there were victims of the paramilitaries, the army, or the state for that purpose.

\section{The Voices}

Piedad, a victim herself, who was kidnapped by the paramilitaries in her efforts to create connections between FARC and the government, told me her story. Despite the difficulties this may bring, she says, 'it is one of the most important things that have happened in my life.' She has mixed feelings about the secretiveness, including the invisible participation of women, arguing that much confidentiality can be very negative. She highlights, as leadership factor, Santos and the delegations' efforts to maintain the process, without giving up to the pressures, despite the moments of crisis. Leadership's connection becomes stronger when the inclusion wasn't limited to one side of the conflict, but open to all. Piedad, as well as Olga Amparo (mentioned earlier), acknowledge that after talking to victims, the delegations recognized the need to listen to those who had been victims also of the state. Piedad states that after this, people testified against the lists DAS (Security Department) would give to the paramilitaries to kill social movement leaders. ${ }^{66}$ The complexity of pleasing millions of victims, however, is undeniable.

Challenges were encountered in this fifth accord as mentioned by Senator Juan Manuel Galán, Liberal Party member and President of the Congress' Commission to oversee victims' reparation and land distribution. He noted that the process had been very inclusive, yet, some complaints were made to him regarding the victims' selection process. Galán, who, on the whole, was in favour of the process, but who provided a critical, objective review, recognized that this should be taken into consideration as some victims felt excluded and marginalized. After an essential comparative analysis, to help understand what went wrong; Grint suggests many approaches to leadership are relevant in the peace process context. Perhaps, the most recent argument he published on leadership was purpose-based. The President and his delegation's purpose was clear from the beginning: To stop conflict and have no more deaths among the Colombian people. This is, then, where they meet, in mutuality, with the majority of the victims.

Senator Galán expressed that in his various visits to victims around the country, those who were most participative in Conferences were women. He recognized

66 Interview with Piedad Córdoba, 2016 
how hard it is to generalize the victims but states that in general, what most victims want is for war to be over, because they have suffered and know what it is. What they most desire is the truth and guarantee of non-repetition'. As an example, former presidential candidate, kidnapped by FARC for almost seven years, Ingrid Betancourt, made a powerful statement during a peace forum: 'it is normal that most who are against this peace process have not suffered the consequences of war, as it is those who have survived a disease, the first to find funds for its cure,' inviting people to own the prospect of peace, 'for us and our future generations to smell the perfume of freedom in all corners of our sacred land'.

Olga Amparo stated that today, 8,300 victims are counted, more than 3 million being women with cases of murder, torture, sexual violence, and continuous threats. Olga, who had worked with multiple victims throughout her life, argues that though the homogeneity of victims is so complex, she found that majority coincide with wanting reparation, and FARC, in this case, assuming responsibility'. A significant number ask for apologies, they want to dialogue, the want to live in peace. They have a common pain.' Piedad, head of one of the commission of victims, indicated that when it came to victims who suffered kidnapping, the majority agreed with the peace process. Similarly, Jairo Gómez, who covered public violence and war in Colombia since the 70s, defined the commissions of victims going to Havana as extremely important for the process because both sides of the table deeply felt people's reality (empathy). Concerning political violence, there were various moments of tension, but the majority of victims asked both sides not to 'stand up from the table,' until peace was signed; until a bilateral ceasefire was agreed. ${ }^{67}$ United Nations sources said in confidence, that there had been innovations in human rights when 'Bringing real life people. People often get in their dogmatism and positions. Bringing victims shows how complex things are'.68

\section{The Power of Leadership}

This interactive process, referred to as leadership, also engaged, in search for collaboration with Cuba and Norway as guarantor countries, and Chile and Venezuela, as observers. Moreover, it brought women, not only as their oftenperceived role of victims, but also as mediators and negotiators. Ana Teresa Bernal, who has not been to Havana, but who has been a mediator in paramilitaries release of hostages in her efforts for peace, has seen a big improvement in inclusion, but argues there is much more to do. She argues 'there have been victims commissions, women advisors, etc. but it should've

\footnotetext{
${ }^{67}$ Interviews with Piedad Córdoba, Jairo Gómez, and Olga Amparo Sánchez

68 Anonymous United Nations source, 2016
} 
been more constant'. Uribe, who has closely followed the process, on the contrary had no comments on the issues of women and victims. He told me 'since the beginning we have expressed our concerns, but our objections have not been heard, we have stated our thesis'. Then, responding to why he hasn't been to Havana representing the opposition, he stated 'through mediators, we have talked to the government, and from here have been very clear of our arguments.' He did not identify any leadership factors and thus in his presidency one of his priorities was women rights, he said he had seen some people taking commissions of victims, but had no opinion on this issue. ${ }^{69} \mathrm{He}$ criticizes the fact that FARC is not paying for victims' reparations (despite being the third richest terrorist group in the world, he argues), and is strongly against amnesty, arguing this would only cause more violence.

Nevertheless, when De la Calle responded to this issue, he said extreme precaution was being taken to avoid criminal gangs, or bandas criminales (bacrim) from emerging, which has happened in the past. Finally, Uribe, who often refers to FARC as terrorists, said there have been no lessons learned from FARC or government. For him, the country was given to FARC. He later invited me to go with him to a leadership Conference he was giving that same afternoon.

La Negra Vasquez (as she likes to be called), former guerrilla member, who served for 20 years in the M19, and reinserted before the 1990 peace process, after her son had died, recognizes a huge increase in women participation from past processes. In proportion, she argues, if we consider that women are half of the members in FARC as well as in the country, 'among the plenipotentiaries, there is no equal representation. When I went to Havana, I was surprised to see so many women Commanders in FARC, who have been for 32 years. Why are they not sitting at the table? They are participating in the negotiations but not as plenipotentiaries'. This reflects, she stated, 'the discrimination against women in the country and in Latin America'. She was happy to hear that if ELN (the second largest guerrillas) started a negotiation, there was already one woman, out of the three chosen plenipotentiaries. In her travels to Havana, as adviser, she vividly recalled that 'there was a respectful listening from the government and FARC: I wish Colombia listened as much as they do at the table. However, there is huge room for improvement in considering us as political subjects in Peace Accords'.

La Negra Vasquez's experience of women's participation also included victims of FARC, who she was with in Havana, from Putumayo, and whom she said greatly supported the process. She said, 'these were humane encounters. If we keep thinking that there are angels and demons, the guilty and the pure, we won't get far. In our democracy, we need a country where we can dissent without killing

${ }^{69}$ Interview, Alvaro Uribe, 2016 
each other'. Ana Teresa and Olga Amparo agreed about the great power of women as tension alleviators and mediators. Olga indicated that in one of her trips to Havana, there were huge fights over issues, and the few plenipotentiaries, like Monica Cifuentes and María Paulina, who were women played a key role in bringing the tone down. Another woman, Colombian Minister of Foreign Affairs, María Angela Olguín, was brought to the table as plenipotentiary towards the end of the agreement. Yet, many times, their role is still limited to making recommendations and contribute, but not as decisionmakers.

Nonetheless, contributions by women tend to greatly influence decision-making. Contrary to what was often found, as women participating from the 'vulnerable community' perspective, the limited research that exists about women participation in peace processes suggests that they are 'more likely to be perceived by fellow citizens as members of society that can be trusted'. Moreover, 'when women's groups were able to strongly influence negotiations or push for a peace deal an agreement was almost always reached... When women's groups were not involved at all, or had a low influence on the process, the chance of reaching an agreement was considerably lower'. ${ }^{70}$ De la Calle said, 'there were two important factors: their presence alone and their amazing role as advisors. Then, it is the first time a sub commission of gender is created, so it turned the Accords to a different direction, and we are very proud of this'. ${ }^{71}$ Women seem to play a key role in what Huber defines as an essential mediation: 'the function is to help parties reframe issues on which they have come to a deadlock'.72

Córdoba, who lost her political rights after the extreme right accused her of being 'FARC ally' said that the government and FARC would call her and ask her to come to Havana as a means of reducing tension and getting to an agreement. The fact that a sub-commission of gender in Havana, with 10 plenipotentiaries each, who acted as advisors, not decision-makers, was created, has also been recognized. Again, the problem seems not to be participation, but visibility and the extent of the participation. Influence was demonstrated after women advocates were able to ensure that the agenda includes all sexual violations against women as not amnestied.

\footnotetext{
70 O’Reilly, Marie, Ó Súilleabháin, Andrea and Paffenholz, Thania (2015), Reimagining Peacemaking: Women's Roles in Peace Processes, (International Peace Institute)

${ }^{71}$ Interview with Humberto De la Calle, 2016

72 Huber, Konrad (2014), Mediation Practice Series - Conflict analysis: the foundation for effective action (Centre for Humanitarian Dialogue)
} 


\section{Underestimating the Power of Leadership}

On the contrary, Admiral Moreno, during his interview asked 'why does leadership matter?' He said he had no insights on the participation of women and victims, while being very critical of the process, but with no clear standing. Burns, Bass, Grint, and Northouse agree that leadership is inclusive, as it is collaborative and collective. This is enough to understand why women, as $51 \%$ of the population, must be included, without a need for evidence of their contribution or lack of it. Moreover, in the delegations' efforts to include women from the civil society, as well as from their sides, at the negotiating table, leadership was exercised. An article from Semana, in a special report, showed the day-to-day of the 20 women, out of the 40 FARC members present in Havana. The arduous job women did in Havana, from being in charge of media to bringing ideas to the sub-commission of gender (which later got to the negotiating table), was reflected in the inclusive language used in the Final Accord document (published in every ethnic language spoken in Colombia). Nevertheless, Colombia's patriarchal culture remains a strong barrier for inclusion.

Monica Rodriguez, who, as a journalist was observer of previous peace processes and recognizes the improvements made, feels this invisibility has to do with two aspects: the patriarchal culture and the confidentiality maintained at the negotiating table. Communication, she indicated, was as a crucial leadership factor. This is also mentioned by most leadership theorists, is what had been missing at some point but this was addressed due to a conscious decision. Senators Paloma Valencia and Alfredo Rangel, both from Uribe's party, have a very similar view of lack of leadership, marginalized participation of women, and manipulation of the victims. Nevertheless, when those from the Centro Democratico were interviewed, sometimes it sounded like a mastered script. They were the opposition but they could not identify any learned lessons, leadership factors, or innovative solutions and were completely against every component of the process. Furthermore, victims, such as the soldier of the Colombian Army, Pablo Moncayo, who was a hostage for 12 years from the age of 18 , declared that they wanted this peace process to happen, even if an imperfect peace, because they did not want what happened to them to happen to anyone else. ${ }^{73}$ What is obvious however, is the wide gap of information between those in favour or hesitant (who get informed), or those who have been to Havana at some point; and those who have not or are against.

\footnotetext{
${ }^{73}$ The New York Times, Aching for Peace but Also Justice, Colombians Weight Deal with FARC, 2016, http://www.nytimes.com/2016/08/26/world/americas/colombia-farc-peacedeal.html?emc=edit_th_20160826\&nl=todaysheadlines\&nlid=57942671
} 
Myths, lies, exaggerations, and calumny were able to spread in big part because of the governments' silence compounding the lack of communication.. Several news articles suggest that when the opposition said something, when comparing it to the Final Accords, it turned out to be a lie or exaggeration. De la Calle did not stop the interventions as the government faced the challenge of a pedagogy marathon before October $2^{\text {nd }}$. In interviews in El Tiempo, he said, that it is possible that they did it wrong. He noted, it has been said that communication has been one of our problems, and it could be'. ${ }^{74}$ This gave all the noise created by those opposed, strength, and I am not talking about those who criticize the process, I thank them for their contribution. I am talking about those who lie about it'. However, now that Final Accords were signed, President Santos referred to this process as a 'comprehensive peace process', and General Mejía, Commander of the Armed Forces, expressed their commitment in receiving FARC no longer as enemies, but as brothers. Strong communication efforts to engage all sectors of society could bring Colombians together to vote for this peace, even if imperfect.

\section{Conclusion}

The concept of leadership is multidimensional, thus extremely complex. Peace processes, in this case, Colombia's last Peace Accords with FARC are not saved from this complexity. The following leadership features were the innovations, which were initially considered: 1) political learning process 2) the collective work and inclusion of the victims and 3) the increased inclusion of women as mediators. In addition, I encountered other factors. Lessons learned from previous peace processes were critical to reaching the Final Accords; and empathy and trust as leadership attributes were shown to be extremely important throughout the whole process and exercised by the government, FARC and different sectors of society. While the engagement of victims and women as mediators was essential to the process, stronger efforts need to be made in the future to have a more holistic inclusion (such as indigenous and afro Colombians). The purpose and process approaches played an important role when victims, and all included in this process, were identified under mutuality and a common purpose: ending conflict. Stronger communication efforts, as leadership suggests, should be made in the future, not necessarily to break confidentiality, but to inform the unpredictable circumstances.

However, leadership was exercised during the Peace Process and its great value was shown to be fundamental. After the delegation went back to Colombia on 25 August 2016, attitudes towards the process changed. Polarization had the country split in half, as exemplified by the initial rejection of the referendum, 
which Santos was well advised not to repeat after the amendments made. As mentioned in the introduction, instead, the revised Accords were put for a vote in Congress, where 90\% voted in favour, passing the Final Peace Accords. Since the implementation phase has started, post conflict efforts including solid educational projects for all those reinserted, but also for the whole of Colombia, will be essential in the implementation of the accords including language, such as referring to each other as Colombians, human beings, and avoiding negative labels. It is now in the hands of Colombians to take this fructuous risk. If it works, present generations would be the last to suffer this war. Leadership will need to continue being exercised, as fundamental to explaining why reaching Final Accords succeeded. The country and the world are expectant to see if the negotiators integrate the Colombian people to engage in a cooperative effort to achieve a life-long dream: peace.

\section{INTERVIEWEES}

A total of 20 interviews were conducted and multiple Conferences and unofficial interviews (not in the list). However, below are only those, which were used for this article. The majority of interviewees agreed to be fully or partially identified, while very few chose to remain anonymous. Most interviews lasted several hours, and some had to be conducted over several days over multiple meetings or conversations.

\section{Colombia:}

All interviews were conducted in 2016 before July $20^{\text {th }}$

Humberto De la Calle, Head of the Colombian Delegation in the table for Colombia's Peace Process in Havana, former Vice President of Colombia. Havana (through video and messages), 2016

Martha Lucía Vazquez, President COLEMPRESARIAS and former Presidency Counsellor for Women Equality, under Uribe’s government, Bogotá, 2016

Piedad Córdoba, former Senator, who served in Congress for over 15 years, nor human rights advocate and leader of movements

Juan Manuel Galán, Senator, Partido Liberal, Bogotaá, 2016

Alvaro Uribe Velez, Senator and leader of the opposition, Centro Democrático, and former President of Colombia (2002-2010), Bogotá, 2016. All interviews conducted with Congressmen were at Congress. 
Admiral David Moreno, former Chief of Staff of the Military, Bogotá, 2016

Paloma Valencia, Senator, Centro Democrático, Bogotá, 2016

Alfredo Rangel, Senator, Centro Democrático, Bogotá, 2016

La Negra Vasquez, former M19 member and board member, and current advocate for peace, Bogotá, 2016

Olga Amparo Sanchez, Director, La Casa de la Mujer (one of the biggest and mos important NGOs advocating for women rights and inclusion), Bogotá, 2016

United Nations Office of Human Rights, 2016

Ana Teresa Bernal, 2016

Olga Behar, award-winner journalist and writer in denouncing corruption, Bogotá, 2016

Gerardo Ardila, former Guerrilla Movement M19 Commander, Bogotá, 2016

Jairo Gómez, war and public order Journalist, Bogotá, 2016

Conversations though mediators with Simón Trinidad, FARC leader in prison in USA, 2016, however, response was not on time to be included in this article.

United Kingdom:

Keith Grint, Professor, Warwick University, London, 2016

\section{BIBLIOGRAPHY}

Arango, Carlos (1984), FARC: Veinte Años de Marquetalia a La Uribe (Bogotá: Ediciones Aurora)

Arnson Cynthia and Cepeda, Ulloa, Fernando (2001), Haciendo Paz: Reflexiones y perspectivas del proceso de paz en Colombia (Bogotá: El Ancora Ediciones)

Bass, Bernard (1990), Handbook of Leadership: Theory, Researh and Managerial Applications (New York: The Free Press)

Benington, John and Turbitt, Irwin (2007), Policing the Drumcree Demonstrations 
in Northern Ireland: Testing Leadership Theory In Practice (SAGE Publications: Los Angeles)

Burns, James (1978), Leadership (New York: Harper \& Row Publishers)

BBC News, 'Colombia-Farc peace process to receive \$450m in US aid,' 2016 http://www.bbc.co.uk/news/world-latin-america-35498357

Echandía Castilla, Camilo \& Escobedo, Rodolfo (1994), Violencia y Desarrollo en el Municipio Colombiano (Bogotá: Presidencia de la República)

Elcock, Howard (2001), Political Leadership (United States: The University of Michigan)

Más de 4 mil casos de falsos positivos son investigados por la Fiscalía, El Espectador, 27 Sep 2014. Available at:

http://www.elespectador.com/noticias/judicial/mas-de-4-mil-casos-de-falsospositivos-son-investigados-articulo-519238 (Accessed 7 September 2015); other news articles were consulted, as the false-positive scandal has been since 2008

Mueren 11 militares en ataque de las FARC al sur de Colombia, El Pais, 15 April 2015. Available at: http://www.elpais.com.uy/mundo/mueren-militares-ataquefarc-sur.html (Accessed 7 September 2015)

El Tiempo, Ingreso de Farc en la política exigirá más a los partidos: De la Calle, 2016. Available at: http://www.eltiempo.com/politica/proceso-depaz/entrevista-a-humberto-de-la-calle/16680496 (Accessed 8 January 2017)

El Tiempo, El fracas de los dialogos de paz en el Caguán, 2010. Available at: http://www.eltiempo.com/archivo/documento/CMS-8430440 (Accessed 8 January 2017)

Grandin, G. and Joseph, G. M. (2010), A Century of Revolution: Insurgency and Counterinsurgency Violence during Latin America's Long Cold War

Guzmán, Fals, Umaña (1963), Violence in Colombia

Grint, Keith (2010), Leadership: A very Short Introduction (Oxford: Oxford University Press)

Grint, Keith, Smolović-Jones, Owain and Holt, Claire (2016), Chapter: What is Leadership: Result, Position, Purpose or Process, or All or None of These? 
Historia: Instituciones de Colombia (2002), Credencial, Colombia

Huber, Konrad (2014), Mediation Practice Series - Conflict analysis: the foundation for effective action, Centre for Humanitarian Dialogue

La Silla Vacia, Lo que esta acrodado, lo que esta apunto de anunciarse, y lo que falta en la Habana, 2016 http://lasillavacia.com/historia/lo-que-esta-acordadolo-que-esta-punto-de-anunciarse-y-lo-que-falta-en-la-habana-56224

McDermott, Jeremy (2014), Las FARC y el narcotráfico: Gemelos siameses? http://es.insightcrime.org/investigaciones/las-FARC-y-narcotrafico-gemelossiameses

Northouse, Peter (2014), Introduction to Leadership: Concepts and Practice, (Michigan: SAGE Publications)

O’Ralley, Marie, Paffenholz, Thania, and ó Súilleabháin (2015), Andrea, Reimagining Peacemaking: Women's Roles in Peace Processes, International Peace Institute https://www.ipinst.org/wp-content/uploads/2015/06/IPI-Epub-Reimagining-Peacemaking-rev.pdf

Palacios, Marco (2012), Public Violence in Colombia, 1958-2010 (Bogotá: Fondo de Cultura Económica)

Peace Forum, Reconciliation: More than a Magical Realism, Bogotá, Colombia, Words by Ingrid Betancourt, 2016

Presidencia de Colombia (Colombia's Government) http://www.dane.gov.co/files/censo2005/etnia/sys/Afro_indicadores_sociode mograficos_censo2005.pdf

Posada, Eduardo (2002), La Paz y sus Principios (Colombia: Alfaomega Colombiana S.A)

Ramírez, Maria Clemencia (2011), Between the Guerrillas and the State: The Cocalero, Movements, Citizenship, and Identity in the Colombian Amazon (Bogotá: INCANH)

Rieff, David (2016), In Praise of Forgetting: historical memory and its ironies (New Haven: Yale University Press)

Semana, 'Tirofijo se Destapa,' (1999), Bogotá 


\section{Semana, 2016, Bogotá}

http://www.semana.com/especiales/escala-violencia-colombia/asesinatosselectivos.html

Semana, Del fusil a los tacones: las mujeres de las FARC en Cuba, 2016

http://www.semana.com/nacion/articulo/dialogos-las-mujeres-de-las-farc-enla-habana/464031

Schulz, John, Analysing your interviews, https://www.youtube.com/watch?v=59GsjhPolPs

The Fog of War Documentary, starring Kennedy's Defence Minister, Robert McNamara, https://www.youtube.com/watch?v=6-AtfrmhrKk

The New York Times, Aching for Peace but Also Justice, Colombians Weight Deal with FARC. Available at:

http://www.nytimes.com/2016/08/26/world/americas/colombia-farc-peacedeal.html?emc=edit th $20160826 \&$ nl=todaysheadlines\&nlid=57942671) (Accesse d 3 January 2017)

Tucker C, Robert (1995), Politics as Leadership (United States: University of Missouri Press)

Vieira, Constanza and Pineda, Chila (2016), Mujeres: Paz, y Política y Poder (Bogotá: Ediciones Aurora)

Villamarín, Pulido, Luis Alberto (1996), The FARC Cartel (Bogotá: Ediciones El Faraon)

Walton, Richard E. (1972), Interorganizational decision making and identity conflict (Chicago: Aldine) 